\title{
Shakespeare and Sexual Politics: Viewing the Tempest and Antony and Cleopatra In The Light Of Kate Millett
}

\author{
Priya Das \\ Guest Lecturer in English at Khalisani Mahavidyalaya, Chandannagar, West Bengal,India
}

\begin{abstract}
My project is directed towards an exploration of women characters in Shakespeare's THE TEMPEST and ANTONY AND CLEOPATRA and how the issue of 'sexual politics' runs rampant in these texts. The study of women and the exploration of this issue of 'sexual politics' of Kate Millett in Shakespeare has not been a self content, marginal enterprise. From the onset it has been clear that the assessment of female characters has direct implication for the status of male characters and the status of Shakespeare. The ultimate issue is succinctly formulated in the introduction to THE WOMAN'S PART (Lenz, Greene, and Neely): "The extent to which Shakespeare aligns himself with patriarchy, merely portrays it, or deliberately criticizes it remains a complex question, one that feminist criticism is aptly suited to address."
\end{abstract}

Keywords: gender, herrschaft, internal colonization, mana, misogyny, patriarchy, sexual politics, sex, taboo.

Submitted Date 17 June 2013

Accepted Date: 22 June 2013

Kate Millett was one of the most prominent figures of the second wave feminists who gave her famous theory of 'sexual politics' in the second chapter ('Theory of Sexual Politics') of the book by the same name-SEXUAL POLITICS published in 1969.

The term 'sexual politics' can strike a bit absurd to any lay reader. The question can at once strike in his mind - Can the relationship between the sexes be viewed in the political light at all? The answer depends on how one defines politics. Politics can be defined as methods or tactics involved in managing a state or government. This is a set of stratagems designed to maintain a system. The term 'politics' shall also refer to power structured relationships and arrangements whereby one group of person controls another group. If we view patriarchy in this light we can conceive it as a similar type of 'political' institution perpetuated by such techniques of control. This is how Kate Millett views the system of patriarchy in the light of politics. Millett's title "Sexual Politics" announces her view of "patriarch', which she sees as pervasive and which demands " a systematic overview - as a Political institution. " [1] Patriarchy subordinates the female to the male or treats the female as an inferior male, and the power is exerted directly or indirectly in civil ordomestic life to constrain women.

Kate Millett has pointed out that the situation between the sexes now, and throughout history, is a case of that phenomenon Max Weber defined as 'herrschaft', a relationship of dominance and sub-ordinance. What remains unacknowledged in our social order is the birthright priority whereby males rule females. Through this system a most ingenious form of "interior colonization" has been achieved. Sexual politics obtains consent through the 'socialization' of both sexes to basic patriarchal politics with regard to temperament, role, and status. Aggression, intelligence, force, and efficacy are the characters attributed to the male, which can be found in many ways to be dominant in the male characters like Prospero, his brother Antonio, Stephano, Caliban and so on. For instance, the aggressiveness of Prospero is well hinted in the way he behaves with Ferdinand-

"Speak not you for him; he's a traitor. - Come,

I'll manacle thy neck and feet together;

Sea water shalt thou drink; thy food shall be

The fresh-brook mussels, withered roots, and husks

Wherein the acorn cradled."

$$
\text { ( i. ii. } 182 \text { ) }
$$

Even Antonio's act of provocation to Sebastian and thereby trying to murder Alonso exposes his aggression. Passivity, ignorance, docility, "virtue", and ineffectuality, on the other hand, are attributed to the females by the patriarchy according to Millett. Both Miranda and her mother fits appropriately to these 'feminine' qualities, while Sycorax, trying to violate these norms and possessing just the opposite traits is held to be a witch, the epitome of all evils, by the patriarchy. On the other hand, the male is always granted a superior status to female. It is the female who are assigned the domestic services and attendance upon infants, while the rest of the human 
achievements, interest, and ambition are conferred upon the male. In THE TEMPEST, Prospero says to Miranda "Here in this island we arrived, and here

Have I, thy schoolmaster, made thee more profit

Than other princes can that have more time

For vainer hours and tutors not so careful."

(i. ii. 161 )

There is no doubt that Prospero nourishes and nurtures Miranda like a princess, but simultaneously deprives her from learning his magical skills. Thus Miranda is only brought up like a 'princess' - an epitome of virtue, for these type of magical skills are restricted only for the patriarchy. And when the witch Sycorax violates this norm, her magic is claimed to be a 'black magic', or witchcraft, in comparison to Prospero's 'white magic'.

Social scientists treat the culturally learned 'female characteristics' (passivity etc) as 'natural'. Kate Millett recognizes that women as well as men perpetuate these attitudes and acts out the sex roles imposed upon them by the patriarchy. We notice these characteristic traits in the dialogues between Ferdinand and Miranda when Miranda says -

"I am your wife, if you will marry me;

If not, I'll die your maid. To be your fellow

You may deny me, but I'll be your servant

Whether you will or no."

( iii. i. 223-224 )

A very similar mentality is exposed through the words of Cleopatra when she says-

“...say to great Caesar this in deputation :

I kiss his conqu'ring hand. Tell him I am prompt

To lay my crown at's feet, and there to kneel..."

(iii.xiii.216)

Thus it is clearly noticeable from both Miranda and Cleopatra's words that they willingly conforms to the literary images of women set by patriarchy and thus helps to perpetuate this political system.

If one takes patriarchal government to be the institution, the principle of patriarchy appears to be two fold : male shall dominate female; elder male shall dominate younger. This is clearly noticeable in $T H E$ TEMPEST whereby Prospero not only rules over Miranda but also exercises his absolute power on the younger men like Ferdinand and Caliban. Prospero says to Caliban -

"... tonight thou shalt have cramps,

Side-stitches, that shall pen thy breath up; urchins

Shall forth at vast of night that they may work

All exercise on thee ..."

(i. ii. 173)

In ANTONY AND CLEOPATRA Octavius Caesar, too, tries to rule over Antony when he finds the later to be "A man who is the abstract of all faults/ that all men follow".(i.iv.114)

Even Caliban, while revolting against Prospero, deliberately paves the way for Stephano to dominate him, as he says -

"Do that good mischief which may make this island

Thine own forever, and I, thy Caliban,

For aye thy foot-licker"

(iv. i. 258 )

Physical strength does not matter in political relations according to Millett. Civilization has always substituted other methods like 'technic', 'weaponry', 'knowledge', for those of physical strength. Physical exertion is considered to be a class factor, those at the bottom performing the most strenuous tasks, whether they are strong or not. Prospero, being a superior male to Caliban dominates him by the means of his magical skills and knowledge which seems to be the primary weapons of him rather than his physical strength. While Caliban belonging from an inferior class is forced to execute all the tasks that require physical exertion; and though he seems to be superior in his physical strength to Prospero, he fails to exert his force or power upon him as well as Miranda, a woman superior to him in power and knowledge and not in physical strength. Prospero thus rightly says to Miranda -

"We cannot miss him; he does make our fire,

Fetch in our wood, and serves in offices

That profit us."

$$
\text { (i. ii. } 171 \text { ) }
$$

Kate Millett observes -

"Male supremacy, like other political creeds, does not finally reside in physical 
strength but in the acceptance of a value system which is not biological." [2]

Miranda, as she says to Ferdinand, is capable of bearing the logs. But Ferdinand addressing her as a "precious creature' refuses to confer her the task as she is a 'princess', and more than that, a female. There is some evidence that fertility cults in ancient society took a turn towards patriarchy, displacing and downgrading female function in procreation and attributing the power of life to the phallus alone. This is clearly evident from Agrippa's speech regarding Cleopatra-

"Royal wench!

She made great Caesar lay his sword to bed.

He ploughed her, and she cropped."

(ii.ii.141)

Patriarchal religion could consolidate this position by the creation of a male god thereby eliminating goddesses and constructing a theology whose basic postulates are male supremacists, and one of whose central functions is to uphold and validate the patriarchal structure. We find that both Caliban and his mother Sycorax worship the male god - Setebos who is actually a deity of the Pantagonians. Millet observes that the patriarchal family insists upon the legitimacy of the young which Bronislaw Malinowski describes as "the principle of legitimacy" formulating it as an insistence that "no child should be brought into the world without a man - and one man at that - assuming the role of a sociological father." [3] By this apparently consistent and universal prohibition, patriarchy decrees that the status of both child and mother is primarily or ultimately dependent upon the male. Prospero in THE TEMPEST, confirms the legitimacy of Miranda based on the words of her late mother -

"Thy mother was a piece of virtue, and

She said thou wast my daughter; and thy father

Was Duke of Milan, and his only heir

And princess, no worse issued"

(i. ii. 153 )

This is quite shameful and unexpected on the part of Prospero. As Orgel indicates -

"She is identified as Miranda's mother in a context implying that though she was

Virtuous, women as a class are not" [4]

While Cleopatra subverts the norms of the patriarchal system by maintaining her relationship with more than one man, she has to suffer for this - she is addressed in derogatory terms by Octavius Caesar or Agrippa and even Antony himself when he calls her a 'Tripple-turned whore' or a 'gipsy' and even a 'witch'. Even Cleopatra realizes towards the end, the outcome, if she surrenders herself to Octavius Caesar-

"Nay, 'ts most certain, Iras. Saucy lictors

Will catch at us like strumpet...

Some squeaking Cleopatra boy my greatness

I'the' posture of a whore"

$$
\text { (v.ii.290-291) }
$$

to Stoller -

Millett finds that while sex is a biological construct, gender is social or psychological. According

"If the proper terms for "sex" are "male" and "female",

The corresponding terms for gender are "masculine" and "feminine". [5]Thus we find that the concept of Egypt as a feminine mysterious country is created by Rome which regards itself to be a masculine power which rules over Egypt.

According to Millett, patriarchy is a peerless governing ideology. No other system, probably, has ever exercised such a complete control over its subjects. This is well justified from Prospero's speech who exercises a complete power over his subjects through out the play -

"That I am Prospero and that very duke

Which was thrust forth of Milan, who most strangely

Upon this shore where you were wrecked, was landed

To be the lord on't ...

This cell's my court; here have I few attendants,

And subjects none abroad."

$$
\text { ( v. i. } 273-274 \text { ) }
$$

Patriarchy's chief institution is the family which is both a mirror of and a connection with the largest society. But as cooperation between the family and the larger society is essential, so the fate of three patriarchal institutions - the family, society, and the state are interrelated. Thus we find in both the text that the 
kings of two countries enter into an alliance through the bond of marriages, which is nothing but a politics of the patriarchal system. Both Miranda and Claribel has been handed in matrimony as an object to ensure a political alliance; they are just a property that has been passed from father to husband. Prospero nurtures, educates, and brings up Miranda as an epitome of ideal woman according to the 'taste' of the patriarchy so that she becomes instrumental in eradicating the previous political dispute and thus paves the way for the creation of a congenial environment. Mrs. Jameson rightly regards Miranda as the 'Eve of an enchanted Paradise', the pure child of nature who is so refined and so elevated above all stain of earth. Interestingly enough, Prospero imposes some rules upon Miranda regarding her meeting with Ferdinand which she deliberately breaks. But if we examine deeply, we will find that the trickery is played by Prospero himself. He creates the norms and disciplines, while he is the one who paves the way for Miranda to break those rules. This seems to be a part of his politics because if Miranda does not meet Ferdinand, then how will they fall in love with each other? And how will the plans of Prospero be succeeded? Quite surprisingly, Miranda fails to understand the trickery and the oppressive nature of the patriarchal society. But even though Cleopatra realizes, she remains helpless and tries her best to win over Octavia when she hears about Antony's marriage with the latter, although it was just a political alliance between Antony and Caesar. Cleopatra, refusing to submit herself to Octavius, embraces death by committing suicide - a very similar conception that Virginia Woolf suggested in her pioneering work "Mrs. Dalloway", that the true emancipation of woman can come only through death. But this should not be the case. In the apparently glorifying portrayal of the death of Cleopatra lies her humiliation by the patriarchy who denies a space to the independent women like Cleopatra.

Henry Maine argues that patriarchal basis of kinship is put in terms of dominion rather than blood; wives, though outsiders, are assimilated into the line, while sister's sons are excluded. In the archaic patriarchal family, Maine observes -

" the group consists of animate and inanimate property, of wife,

children, slaves, land and goods, all held together by subjection to the

despotic authority of the eldest male". [6]

Being the elder brother, Prospero is the legal Duke of Milan, and though he was thwarted from his dukedom by his younger brother Antonio, he ultimately gains back his position through his power and magical skill. On the other hand, Ferdinand declares Miranda to be the future queen of his kingdom when he will marry her -

" $\mathrm{O}$, if a virgin,

And your affection not gone forth, I'll make you

The Queen of Naples".

(i. ii. 181 )

But when Miranda, after becoming the wife of Ferdinand will be the partner of his property, Claribel, his sister will disinherit it according to the rules of patriarchy. But the most interesting thing according to this system of patriarchy is that, Ferdinand is going to be the heir of both of Naples as well as of Milan - the former that he inherits from his father while the later as a dowry from his father-in-law, that is, Prospero. Thus the position of women in patriarchal society is a continuous function of their economic dependence.

While the romantic love tradition according to Millett's theory, pardons female for sexual activity, we find Cleopatra to be ultimately punished and treated as a whore. Prospero, on the other hand, imposes restrictions upon Miranda in order to preserve her virginity -

"If thou dost break her virgin-knot before

All sanctimonious ceremonies may

With full and holy rite be ministered,

No sweet aspersion shall the heavens let fall

To make this contract grow; but barren hate,..."

(iv. i. 243)

There is no doubt that Miranda has a paradoxical role in the play. She is the dependant female who is, however, a key element in the dynamics of power. Leininger observes that she is crucial for the action of the play and yet she is "deprived of any possibility of human freedom, growth or thought. She need only be chaste - to exist as a walking emblem of chastity". [7] Even Gonzalo's Utopia seems to preserve women who are both "innocent and pure".

Traditionally, the white male has been accustomed to concede the female of his own race, in her capacity as " his woman", a higher status than that ascribed to the black male. Besides the "matriarchal' aspect of black society and the 'castration' of the black male are the most deplorable symptoms of black oppression in white racist society. In THE TEMPEST , Caliban has been ascribed the status of a servant to Miranda. Miranda says to Caliban -

$$
\text { “...But thy vile race }
$$

(Though thou didst learn) had that in’t which good natures 
Could not abide to be with; therefore wast thou

Deservedly confined into this rocks,

Who hadst deserved more than a prison."

(i. ii. 175 )

Egypt, on the other hand, is a matriarchal society - a feminine world ruled by a non-white woman like Cleopatra who has full access to public and private spheres as the ruler of Egypt. Egypt is thus viewed as a female dominating society which promotes freedom, indulgence, hedonism and hence is prohibited by Rome which promotes self-deprivation.

Patriarchal force, according to Millett, also relies on a form of violence particularly sexual in character and realized most completely in the act of rape. Millet views that in rape,

"the emotions of aggression, hatred, contempt and the desire to break or violate

personality, take a form consummately appropriate to sexual politics". [8]

Caliban very subtly uses this policy to gain control over the whole island by trying to rape Miranda after which he would have "peopled else / This isle with Calibans" ( i. ii. 175 ). But when his plan fails, he very cunningly imposes this task of exploitation and the execution of Prospero as well to Stephano. But why did Caliban wanted to exploit Miranda? Is it only to gain control over this island? It is possible that behind his motive of conquering, lies his hatred and a sadistic attitude towards Miranda who is equally instrumental in making a slave out of him. Being a male it was in his instinct to oppress a female and not to become an oppressed by her. While, if we consider Ariel, the airy spirit, to be a female which is quite evident in the use of such adjectives like 'dainty', or 'harmless fairy', then it is quite clear that the duke exploits her by subjugating and making a slave out of her. And though he promises to release her after the completion of her task, there is no hint at the fact that he really releases her from his grip.

Primitive society, according to Millett, practices its misogyny in terms of 'taboo' and 'mana' which evolved into explanatory myth. In the two leading myths of Western culture - the classical tale of Pandora's Box and the Biblical story of the Fall, earlier mana concepts of feminine evil have passed through a final literary phase to become highly influential ethical justification of things as they are. Pandora appears to be discredited version of a Mediterranean fertility goddess, the origin of "the damnable race of women - a plague which men must leave with". [9] It has been said that the evils of the male human condition came through the introduction of the female and her unique product, which is sexuality. Hesiod represents Pandora as a perilous temptation with 'the mind of a bitch and a thievish nature', full of cruelty of desire and longings that wear out the body, lies and cunning words and a deceitful soul, a snare sent by Zeus to be 'the ruin of men'. In ANTONY AND CLEOPATRA, Cleopatra is presented as the image of Pandora who is held solely responsible for the fall of Antony; while Egypt symbolizes the vulva or hymen- Pandora's "Box". Caesar and the Romans demonize her as a woman ruler whose power was fatally inflected by her sexuality. She thus seems to play an active role of the quintessential Eve responsible for the fall of her Adam-Antony. In THE TEMPEST, too, Sycorax can also be seen as a Pandoric figure with whom vile evils like slavery, black magic, etc enter the Utopian island of which Ariel was once the sole master. Shakespeare seems to conform to the ideas of patriarchal ideology who, though seems to appreciate the intelligence at work in his femme fatale characters like Cleopatra and Sycorax, allowing them to manipulate the men around them, his retribution is brutal and unforgiving. According to Millett, -

"What requires further emphasis is the responsibility of the female, a marginal creature in bringing plague in the male world and the justice of her suborned condition as dependent on her primacy role in this original $\sin " .[10]$

The connection of women, sex, and sin constitutes the fundamental patterns of Western patriarchal thought. According to many scholars, Sycorax is closely related to Medea of Ovid's METAMORPHOSIS. Kamau Brathwaite observes-

" [ Sycorax is ] a paradigm for all women of the Third World, who have not yet, despite all the effort, reached that trigger of visibility which is necessary for a whole society". [11]

Even Prospero talks of her power-

“... This misshapen knave,

His mother was a witch, and one so strong

That could control the moon, make flows and ebbs,

And deal in her command without her power". (v. i. 281 )

Perhaps patriarchy's greatest psychological weapon is simply its universality and longevity. So when a system of power is thoroughly in command, it has scarcely need to speak itself aloud : when its workings are exposed and questioned, it becomes not only subject to discuss but even to change. 
So this project of mine subtly and systematically illuminates Shakespeare's acknowledgement of the fact of what it is to be fully woman - the increasing contradictions, the inescapably oxymoronic nature of our life, especially in the area of sex and love. The analysis of gender and sexuality allows us to understand the variety of ways that Shakespeare responded imaginatively to sex, gender, and sexuality as crucial determinant of human identity and political power. It is his supremacy in this territory which makes him so much the greatest of writers, effortlessly eclipsing his closest literary rivals.

\section{References}

[1]. Raman Seldon, Peter Widdowson and Peter Brooker, A READER'S GUIDE TO CONTEMPORARY LITERARY THEORY. (India : Kindersley, 2007. Print.)

[2]. Kate Millett, SEXUAL POLITICS. (1969). ( University of Illinois Press, 2000. Print.)

[3]. Kate Millett, SEXUAL POLITICS. (1969). ( University of Illinois Press, 2000. Print.)

[4]. Sofia Valdivieso, "Double Erasure in THE TEMPEST : Miranda in Postmodern Critical Discourse". (Web. 9 $9^{\text {th }}$ Aug. 2011. $<$ http : // dialnet. Unirioja. es. >.)

[5]. Kate Millett, SEXUAL POLITICS. ( 1969 ). ( University of Illinois Press, 2000. Print.)

[6]. Kate Millett, SEXUAL POLITICS. (1969). ( University of Illinois Press, 2000. Print.)

[7]. Sofia Valdivieso, "Double Erasure in THE TEMPEST : Miranda in Postmodern Critical Discourse". ( Web. 9 ${ }^{\text {th }}$ Aug. 2011. $<$ http : // dialnet. Unirioja. es. >.)

[8]. Kate Millett, SEXUAL POLITICS. (1969 ). (University of Illinois Press, 2000. Print.)

[9]. Kate Millett, SEXUAL POLITICS. (1969). ( University of Illinois Press, 2000. Print.)

[10]. Kate Millett, SEXUAL POLITICS. (1969). ( University of Illinois Press, 2000. Print.)

[11]. Kamau Brathwaite, “Sycorax's book”. BARABAJAN POEMS. ( 1994 ). (University of Oklahoma, 1994. Web. $20^{\text {th }}$ Aug. 2011. < http : // en. wikipedia. org. >.)

[12]. Shakespeare, William. THE TEMPEST. ( 1623 ). (Ed. Virginia M. Vaughan and Alden T. Vaughan. Singapore: Thomson Asia Pte Ltd, 2001. Print.)

[13]. Shakespeare, William. ANTONY AND CLEOPATRA. ( 1607 ). (Ed. John Wilders. India: Saurabh, 2008. Print.) 